FisiPublik : Jurnal IImu Sosial dan Politik

https://journal.uwgm.ac.id/index.php/fisipublik

P-ISSN: 2528-2689; E-ISSN: 2540-9751

Vol 04 No 01 Mei 2019,

\title{
Sistem Pengendalian Intern Pemerintah di Inspektorat Provinsi Kepulauan
}

\section{Riau}

\author{
Agus Supriono $^{1}$, Suhardi Mukhlis ${ }^{2}$, Shahril Budiman ${ }^{3}$
}

123Program Studi Ilmu Pemerintahan, Sekolah Tinggi Ilmu Sosial Dan Ilmu Politik

Raja Haji Tanjungpinang

Email: info@stisipolrajahaji.ac.id, suhardimuklis@stisipolrajahaji.ac.id,

shahri12204@gmail.com

\begin{abstract}
Abstrak
Dalam rangka menuju good governance reformasi birokrasi dengan menerapkan prinsip transparansi dan akuntabilitas merupakan salah satu syarat dan upaya dalam penguatan penyelenggaraan pemerintahan. Dalam melaksanakan Amanat dari Peraturan Pemerintah Nomor 60 Tahun 2008 Sistem Pengendalian Intern Pemerintah hadir untuk dapat menghindari terjadinya penyimpangan, ketidakpatuhan, dan penyalahgunaan wewenang yang dapat merugikan keuangan negara. Dengan menerapkan lima unsur SPIP yaitu lingkungan pengendalian, Penilaian Resiko, Kegiatan Pengendalian, Informasi dan Komunikasi, serta Pemantauan. Adapun tujuan dari penelitian ini yaitu untuk mengetahui sistem pengendalian intern pemerintah di Inspektorat Provinsi Kepulauan Riau dan untuk mengetahui hambatan-hambatan yang terjadi dalam penerapan lima (5) unsur sistem pengendalian intern pemerintah di Inspektorat Provinsi Kepulauan Riau yang dimaksud. Metode penelitian yang digunakan dalam penelitian ini adalah metode deskriptif dengan pendekatan kualitatif. Pengambilan sempel dengan menggunakan purposive sampling, dengan mengambil sampel sebanyak 7 orang dari pimpinan dan pegawai di inspektorat Provinsi Kepulauan Riau. Dari hasil analisis bahwa dalam sistem pengendalian intern pemerintah di Inspektorat Provinsi Kepulauan Riau menggunakan unsur lingkungan pengendalian, dengan penegakan nilai etika dan intergritas dalam organisasi yang dicontohkan dengan keteladanan sikap dan prilaku pimpinan, dan komitmen pimpinan terhadap kompetensi pegawai, dari penilaian resiko, di lihat dari penentuan titik kritis suatu kegiatan yang dapat menimbulkan resiko terhambatnya pencapaian target kegiatan, mengidentifikasi resiko yang mungkin terjadi yang dapat menimbulkan dampak negatif dengan tingkat resiko tinggi, sedang dan rendah, dan juga mengidentifikasi potensi kendala yang akan dihadapi dari resiko. Kegiatan pengendalian dilihat dari membuat laporan trasnsaksi keuangan, setiap kegitan dan mencatat dan mendokumentasikan dengan lengkap dan akurat atas seluruh aset yang ada di inspektorat, informasi dan komunikasi dilihat dari segi keterbukaan informasi anggaran, komunikasi seluruh pegawai dalam memberikan saran perbaikan, jika terjadi kesalahan penyusunan target dab transaksi keuangan suatu kegiatan, dan dilihat dari pemantauan pengendalian dengan segi membandingkan dokumen RTP dengan anggaran yang tersedia, memantau belanja dan data aset kegiatan sesuai dengan standart satuan harga, melakukan rekonsiliasi aset setiap bidang kegiatan dan elauasi laporan RTP setiap kegiatan bidang.
\end{abstract}

Kata Kunci : Pengendalian, Pemerintah, SPIP 


\title{
The Internal Control System Inspectorate Riau Islands Province
}

\begin{abstract}
In order to get good governance bureaucracy reform by applying the principle of transparency and accountability is one of the requirements and efforts in strengthening the governance. In implementing the mandate of Government Regulation No. 60 of 2008 the Government's Internal Control System is present in order to avoid the occurrence of irregularities, non-compliance, and abuse of authority that can harm the state finances. By applying the five elements of the Government Internal Control System, namely the control environment, Risk Assessment, Control Activities, Information and Communication, and Monitoring. The purpose of this study is to determine the internal control system of the government in the Inspectorate of Riau Islands Province and to know the obstacles that occur in the application of five elements of internal control system of the government in the Inspectorate of Riau Islands Province in question The research method used in this research is descriptive method with qualitative approach. Sempel collection by using purposive sampling, by taking samples of seven people from the leadership and employees in the Riau Islands Province inspectorate. From the analysis that in the internal control system of the government in the Inspectorate of Riau Islands Province using the elements of control environment, with the enforcement of ethical values and organizational integrity exemplified by exemplary attitudes and leadership behaviors, and leadership commitment to employee competence, from risk assessment, in view of the determination of a critical point of an activity that may pose a risk of inhibiting the achievement of the targets of activities, identify risks that may occur that can cause negative impacts with high risk levels, medium and low, and also identify potential obstacles to be faced from risk. Control activities are seen from making financial transactions reports, every activity and record and document the complete and accurate of all assets in the inspectorate, information and communication viewed from the aspect of budget information disclosure, communication of all employees in providing suggestions for improvement, in case of mistakes in the preparation of targets and financial transactions of an activity, and viewed from control monitoring in terms of comparing RTP documents with available budget, monitoring expenditure and activity asset data in accordance with the standard unit standard, reconciling assets of each activity field and eleating the Action Plan Report of each field activity.
\end{abstract}

Keywords: Control, Government,SPIP 
FisiPublik : Jurnal IImu Sosial dan Politik

https://journal.uwgm.ac.id/index.php/fisipublik

P-ISSN: 2528-2689; E-ISSN: 2540-9751

Vol 04 No 01 Mei 2019,

\section{Pendahuluan}

Salah satu upaya nyata yang dilakukan pemerintah sebagai wujud dari semangat reformasi birokrasi adalah melakukan penataan ulang terhadap sistem penyelenggaraan pemerintahan dengan menerapkan prinsip-prinsip Transparansi dan Akuntabilitas yang merupakan pondasi dasar untuk mewujudkan tata kelola pemerintahan yang baik dan bersih (Good Governance). Untuk melaksanakan pengawasan dan pengendalian atas kegiatan-kegiatan pemerintah dalam mengelola uang negara dibutuhkan sebuah sistem yang mampu mencegah terjadinya segala bentuk penyimpangan, penyalahgunaan, ketidakpatuhan dan kecurangan yang dapat merugikan keuangan negara.

Kegiatan yang dilaksanakan oleh sebuah instansi pemerintah mulai dari perencanaan, pelaksanaan, pengendalian, pengawasan, sampai dengan pertanggungjawaban harus dilaksanakan secara tertib, terkendali, dan harus memenuhi prinsip efektivitas dan efisiensi. pengendalian sebagai bagian dari serangkaian kegiatan yang bersifat terus menerus dilakukan oleh atasan langsung terhadap bawahannya secara Preventif dan Represif agar pelaksanaan tugas bawahan tersebut berjalan secara efektif dan efisien sesuai dengan rencana yang telah ditetapkan dan mematuhi peraturan yang berlaku.

Dalam rangka melaksanakan amanat Peraturan Pemerintah Nomor 60 Tahun 2008 tentang Sistem Pengendalian Intern Pemerintah (SPIP) sebagai upaya penguatan efektivitas penyelenggaraan pemerintahan salah satunya dengan melaksanakan Sistem Pengendalian Intern Pemerintah di lingkungan Pemerintah Provinsi Kepulauan Riau yang bertujuan agar apa yang direncanakan dapat dilaksanakan dengan baik sesuai target dan tujuan yang ingin dicapai. Banyaknya nya temuan hasil audit kegiatan SKPD provinsi kepulauan riau sebagaimana tertera pada tabel I.1 berdasarkan dari temuan Inspektorat Provinsi Kepulauan Riau dari data Rekapitulasi temuan tindak lanjut hasil pemeriksaan diketahui bahwa : 
FisiPublik : Jurnal IImu Sosial dan Politik

https://journal.uwgm.ac.id/index.php/fisipublik

P-ISSN: 2528-2689; E-ISSN: 2540-9751

Vol 04 No 01 Mei 2019,

Tabel 1

Data Temuan Kesalahan Administratif Dan Temuan Transaksi Keuangan Seluruh SKPD Provinsi Kepulauan Riau

\begin{tabular}{|c|c|l|}
\hline No & \multicolumn{1}{|c|}{ Tahun } & \multicolumn{1}{c|}{ Jumlah Temuan } \\
\hline 1 & 2013 & $\begin{array}{l}219 \text { temuan Kesalahan Administratif dan } \\
\text { Transaksi Keuangan }\end{array}$ \\
\hline 2 & 2014 & $\begin{array}{l}130 \text { temuan Kesalahan Administratif dan } \\
\text { Transaksi Keuangan }\end{array}$ \\
\hline 3 & 2015 & $\begin{array}{l}108 \text { temuan Kesalahan Administratif dan } \\
\text { Transaksi Keuangan }\end{array}$ \\
\hline
\end{tabular}

Sumber: Rekapitulasi Temuan Tindak Lanjut Laporan Hasil Pemeriksaan Inspektorat Provinsi Kepulauan Riau

Oleh karenanya ini menjadi pertanyaan besar bagi Sistem Pengendalian Intern dalam penatausahaan pengelolaan keuangan daerah guna menjaga integritas aparatur maupun organisasi kelembagaan. Jika melihat pentingnya peran SPIP dalam rangka mencapai tujuan seharusnya tidak terjadi kesalahan-kesalahan administratif dan transaksi keuangan dalam penyelenggaraan pemerintahan dan sasaran organisasi serta untuk mewujudkan tata kelola pemerintahan yang baik maka pimpinan instansi/organisasi harus dapat menjadikan penerapan SPIP sebagai tanggung jawab bersama tidak hanya pada unit kerja terkecil tapi hingga kepada masing-masing individu. Selain itu, perlu diingat bahwa SPIP bukan hanya upaya membentuk mekanisme administratif saja tetapi juga upaya melakukan perubahan sikap dan perilaku (Soft Factor). Peraturan yang ada bukan merupakan akhir namun merupakan awal dari langkah perbaikan. Oleh Karena itu SPIP sangat bergantung kepada komitmen, teladan pimpinan dan niat baik dari seluruh elemen pejabat dan pegawai instansi pemerintah. Adapun unsur Sistem Pengendalian Intern Pemerintah mengacu pada konsep Peraturan Pemerintah Nomor 60 Tahun 2008, yaitu meliputi:

1. Lingkungan pengendalian

2. Penilaian risiko

3. Kegiatan pengendalian

4. Informasi dan komunikasi

5. Pemantauan pengendalian intern 
FisiPublik : Jurnal IImu Sosial dan Politik

https://journal.uwgm.ac.id/index.php/fisipublik

P-ISSN: 2528-2689; E-ISSN: 2540-9751

Vol 04 No 01 Mei 2019,

Lingkungan Pengendalian dimaknai sebagai suatu kondisi di dalam instansi pemerintah dalam hal ini inspektorat provinsi kepulauan riau yang dapat mempengaruhi efektifitas Pengendalian Internal dalam instansi dengan menekankan pimpinan maupun seluruh pegawai harus dapat menciptakan dan memelihara keseluruhan lingkungan organisasi yang dapat menimbulkan prilaku positif dan mendukung pengendalian intern dan manajemen yang sehat dalam usaha bersama mencapai tujuan organisasi. Penilaian resiko adalah suatu kegiatan penilaian atas kemungkinan kejadian yang dapat mengancam pencapaian tujuan dan sasaran instansi pemerintah. Kegiatan pengendalian dimaknai sebagai tindakan untuk mengatasi resiko serta penetapan dan pelaksanaan kebijakan serta prosedur untuk mengatasi tindakan yang dilakukan sudah tepat dan efektif. Informasi dan komunikasi dimaknai sebagai data - data yang diolah yang nantinya dapat digunakan dalam pengambilan keputusan dalam rangka menyelenggarakan tugas dan fungsi inspektorat. Pemantauan dan monitoring dilakukan guna memastikan apakah SPIP sudah berjalan sebagaimana yang diharapkan dan tindakan perbaikan yang telah dilaksanakan sudah sesuai dengan perkembangan.

Sistem Pengendalian Intern Pemerintah adalah proses yang Integral pada tindakan dan kegiatan yang dilakukan secara berkelanjutan oleh seluruh pihak dalam instansi pemerintah baik pimpinan dan seluruh pegawai untuk memberikan keyakinan memadai atas tercapainya tujuan organisasi melalui kegiatan yang efektif dan efisien. Wilopo (2006) menyatakan bahwa Sistem Pengendalian Intern Pemerintah meliputi berbagai kebijakan dan prosedur, diantaranya: terkait dengan catatan keuangan, menyediakan keyakinan yang memadai bahwa laporan tersebut telah sesuai dengan Standar Akuntansi Pemerintahan dan penerimaan serta pengeluaran telah sesuai dengan otorisasi yang diberikan, menyediakan keyakinan yang memadai atas keamanan aset daerah yang berdampak material pada laporan keuangan.

Inspektorat Provinsi Kepulauan Riau merupakan salah satu satuan perangkat kerja daerah (SKPD) provinsi kepri sesuai dengan Peraturan daerah provinsi kepulauan riau nomor 5 tahun 2011 tentang organisasi dan tata kerja 
FisiPublik : Jurnal IImu Sosial dan Politik

https://journal.uwgm.ac.id/index.php/fisipublik

P-ISSN: 2528-2689; E-ISSN: 2540-9751

Vol 04 No 01 Mei 2019,

(SKPD) dilingkungan Provinsi Kepulauan Riau dan Peraturan Gubernur Kepulauan Riau nomor 21 tahun 2012 tentang Tugas, fungsi, dan uraian tugas Inspektorat provinsi kepulauan riau dalam hal iniyang bertangungjawab langsung kepada Gubernur dalam menjalankan fungsi pengawasan pengendalian, dan pembinaan terhadap seluruh penyelenggaraan dan pengelolaan program kegiatan di seluruh SKPD di lingkungan Pemerintah Provinsi Kepulauan Riau.

Dalam pelakasanaan 4 fungsi Pemerintahan yaitu Pengaturan, Pembangunan Pemberdayaan, dan Pelayanan. SPIP masuk di fungsi Pengaturan dalam penyelenggara pemerintahan karena dasar kebijakan dan peraturanperaturan menjadi tolah ukur utama dalam pelaksanaan SPIP. SPIP merupakan salah satu program kegiatan pengendalian yang dilaksanakan di lingkungan Inspektorat Provinsi Kepulauan Riau sendiri yang bertujuan agar pelaksanaan kegiatan yang sesuai dengan perencanaan yang telah ditentukan dan mematuhi peraturan yang berlaku sehingga terhindar dari ketidakpatuhan dan penyimpangan dalam menjalankan program kegiatan.

Adapun Tugas Pokok dan Fungsi Inspektorat dalam Penyelenggaraan Pemerintah, adalah sebagai berikut :

1. Melakukan Pengendalian terhadap penyelenggaran Pemerintah dari mulai proses perencanaan, Pelaksanaan, Pertanggungjawaban serta evaluasi seluruh program kegiatan SKPD dilingkungan Provinsi Kepri.

2. Melakukan Pengawasan program kegiatan seluruh SKPD dalam mencegah terjadinya penyimpangan keuangan daerah.

3. Melakukan pembinaan kepada seluruh SKPD pemerintah daerah jika terdapat kesalahan penyelenggaraan admnistrasi dan pengambilan kebijakan.

Selanjutnya adapun dasar kebijakan daripenyelengaraan SPIP di Inspektorat adalah dengan terbitnya Peraturan Gubernur Kepulauan Riau Nomor 16 Tahun 2010 tentang Penyelenggaraan Sistem Pengendalian Intern Pemerintah (SPIP) di lingkungan Pemerintah Provinsi Kepulauan Riau Tanggal 03 Mei 2010 dan diteruskan dengan Keputusan Gubernur Kepulauan Riau Nomor 370 Tahun 2011 tentang Petunjuk Pelaksanaan Penyelenggaraan SPIP di lingkungan Pemerintah Provinsi Kepulauan Riau Tanggal 25 Agustus tahun 2011. Seharusnya SPIP dilakukan agar dapat memberikan keyakinan yang memadai bahwa belanja suatu kegiatan dapat dikelola dengan baik, tepat sasaran, dan pertanggungjawaban 
FisiPublik : Jurnal IImu Sosial dan Politik

https://journal.uwgm.ac.id/index.php/fisipublik

P-ISSN: 2528-2689; E-ISSN: 2540-9751

Vol 04 No 01 Mei 2019,

yang transparan. Namun pada kenyataanya penulis melalui observasi awal menemukan beberapa gelaja pemasalahan yaitu:

1. Satuan tugas (SATGAS) SPIP inspektorat provinsi kepulauan riau menyusun dan membuat dokumen rencana tindak pengendalian terhadap seluruh kegiatan di inspektorat provinsi kepulauan riau.

2. Melakukan pemantauan terhadap hasil tindak pengendalian yang dilakukan diseluruh unit bidang terhadap seluruh kegiatan di Inspektorat Provinsi Kepri.

Dari beberapa gejala permasalahan tadi penulis berkeyakinan masih terdapat kekurangan dalam tahap persiapan penerapan SPIP sebelum masuk ketahap penyelenggraan SPIP dilingkungan Inspektorat Provinsi Kepulauan Riau. Penulis berharap dengan adanya komitmen pimpinan dalam hal ini Inspektur Provinsi Kepulauan Riau untuk memberikan perhatian terhadap persiapan Tim Satgas SPIP di Inspektorat Provinsi Kepulauan Riauadalah hal yang paling penting dan merupakan prasyarat dalam penyelenggaraannya. Berdasarkan Uraian-uraian di atas, maka peneliti memilih judul"Sistem Pengendalian Intern Pemerintah (SPIP) pada Inspektorat Provinsi Kepulauan Riau”.

\section{Metode Penelitian}

Penelitian ini memakai jenis penelitian "Deskriptif pendekatan kualitatif" . Deskriptif pendekatan kualitatif dapat didefinisikan sebagai berikut: Menurut Lincolen dan Guba "Penelitian dimulai dengan asumsi bahwa konteks itu kritis masing-masing konteks itu ditangani dari segi bentuknya sendiri" (Moleong, 2007). Menurut Bogdan dan Taylor, "Metode kualitatif sebagai prosedur penelitian menghasilkan data deskriptif berupa kata-kata tertulis atau lisan dari orang-orang dan prilaku yang dapat diamati yang holistik(utuh)" (Moleong, 2007). Penelitian Deskriptif adalah penelitian yang dilakukan untuk mengetahui nilai variabel mandiri, baik satu satu variabel atau lebih tanpa membuat perbandingan atau menghubungkan variabel ( Sugiyono.2005)

Tempat dan lokasi penelitian dipusat di Inspektorat Provinsi Kepulauan Riau. Kompleks perkantoran Gubernur Kepulauan Riau Gedung C-1 Lantai 2 Dan 
FisiPublik : Jurnal IImu Sosial dan Politik

https://journal.uwgm.ac.id/index.php/fisipublik

P-ISSN: 2528-2689; E-ISSN: 2540-9751

Vol 04 No 01 Mei 2019,

3 Pulau Dompak Tanjungpinang. Alasan penulis memilih lokasi penelitian tersebut adalah sebagai berikut :

Saya tertarik meneliti di Inspektorat Provinsi Kepulauan Riau karena saya melihat bagaimana SPIP diterapkan dan dilaksanakan sesuai dengan Peraturan Gubernur Nomor 16 Tahun 2010 Tentang Penyelenggaraan Sistem Pengendalian Intern Pemerintah Dilingkungan Pemerintahan Provinsi Kepulauan Riau Dan Keputusan Gubernur Kepulauan Riau Nomor 370 Tahun 2011 Tentang petunjuk Pelaksanaan Penyelenggaraan SPIP Di Provinsi Kepulauan Riau. Inspektorat Provinsi Kepulauan Riau merupakan satuan kerja perangkat daerah (SKPD) yang mempunyai tugas pokok dan fungsi pengawasan, pengendalian, dan pembinaan terhadap penyelenggaraan pemerintahan khususnya mengenai Sistem Pengendalian Intern Pemerintah.

\section{Pembahasan}

\section{Lingkungan Pengendalian}

a) Integritas dan nilai etika didalam organisasi yang dicontohkan dengan keteladanan sikap dan perilaku pimpinan

Dalam lingkungan pengendalian untuk melihat integritas dan nilai etika didalam organisasi dimulai dari Pimpinan yang memberikan cerminan keteladanan sikap dan perilaku kepada para pegawai untuk dicontohkan dan diterapkan dalam pelaksanaan pekerjaan. Dengan contoh mentaati waktu jam kerja sesuai jadwal, memberi semangat dan masukan masukan positif kepada bawahan terhadap palaksanaan tugas masing masing pegawai. contoh yang kedua membuat Pakta Integritas antara Inspektur Provinsi Kepri dengan Sekretaris, Inspektur Pembantu Bidang I, II, dan III untuk tidak melakukan tindakan korupsi, Kolusi, dan Nepotisme dalam pelaksanaan Tugas Pokok dan Fungsi di seluruh program kegiatan yang di kuasakan dan dilaksanakan oleh Inspektur. Dan terintegrasi kebawah sampai ke level Staf. Contoh yang ketiga dengan membuat Sasaran kerja pegawai yang isinya akan terlihat Pembagian tugas yang jelas sasaran, dan terget dalam pelaksanaan kegiatan yang berdampak 
FisiPublik : Jurnal IImu Sosial dan Politik

https://journal.uwgm.ac.id/index.php/fisipublik

P-ISSN: 2528-2689; E-ISSN: 2540-9751

Vol 04 No 01 Mei 2019,

kepada Kinerja sesuai tugas pokok dan fungsi masing masing pegawai. Dari wawancara yang dilakukan terhadap informan, maka dapat dianalisa bahwa Inspektur provinsi kepulauan riau belum sepenuhnya mencontohkan keteladanan sikap dan prilaku melalui ketaatan waktu terhadap jam kerja pegawai namun dengan informasi yang didapatkan sering pulang cepat sebelum waktu jam kerja pegawai tiba. Namun dalam hal memberikan semangat dan masukan positif dengan mengadakan rapat rapat rutin yang tujuannya membentuk pola komunikasi yang baik untuk pencapaian target kinerja organisasi prilaku inspektur sudah cukup baik dengan mengumpulkan para KPA dan PPTK pertiga bulan sekali dalam membahas target dan realisasi kegiatan yang tentunya akan berdampak kepada kinerja organisasi secara keseluruhan walapun rapat tersebut tidak melibatkan staf secara keseluruhan karena dari hasil hasil rapat dengan para petinggi harusnya diintegrasikan oleh Inspektur Pembantu dan Sekretaris selaku kuasa pengguna anggaran melalui kasubag masing selaku pejabat teknis pelaksana kegiatan kebawahannya masing masing.

Selanjutnya dalam penegakan integritas inspektur dengan sekretaris dan para inspektur pembantu telah membuat perjanjian dalam bentuk dokumen pakta integritas untuk tidak melakukan tindakan korupsi, kolusi, dan nepotisme dalam pelaksanaan tugas dan fungsi pegawai yang tentunya berkaitan dengan anggaran dan jabatan yang diamanahkan. Serta seluruh pegawai wajib menandatangani sasaran kerja pegawai yang isinya pembagian tugas dan fungsi yang jelas diseluruh bidang di lingkungan inspektorat provinsi kepulauan riau dan ini merupakan bentuk pembagian tugas yang konkrit dalam penegakan integritas di lingkungan inspektorat provinsi kepulauan riau. Oleh karena itu saya berusaha mencari data lain sebagai contoh melalui absen manual apel pagi, absen print out finger print yang telah di verifikasi badan kepegawaian dan diklat dari bulan januari sampai dengan juni 2017 dan amprah gaji tunjangan prestasi kerja yang menjadi tunjangan potongan atas ketidakhadiran dan keterlambatan absen figer print. apakah benar inspektur dan seluruh pegawai hadir tepat waktu 
FisiPublik : Jurnal IImu Sosial dan Politik

https://journal.uwgm.ac.id/index.php/fisipublik

P-ISSN: 2528-2689; E-ISSN: 2540-9751

Vol 04 No 01 Mei 2019,

sesuai jam kerja pegawai. Mengenai pakta integritas apakah ada bukti penandatangan pakta integritas antara inspektur dengan sekretaris, inspektur pembantu dan seluruh staf. Dan apakah jika ada pakta integritas sudah menjamin seluruh pagawai di jauhkan dengan tindajan penyimpangan dan prilaku negatif. Mengenai sasaran kerja pagawai apakah ada dokumen SKP untuk seluruh pegawai di inspektorat provinsi kepulauan riau. Hal ini tak luput dari kesadaran diri dari para seluruh pegawai SPIP dalam mematuhi aturan kerja SOP. Langkah-langkah secara rinci dan sistematis dari SOP Rekapitulasi Daftar Hadir Pegawai terkait dengan kinerja setiap kegiatan yaitu mengidentifikasikan mutu baku tertentu, meliputi waktu yang diperlukan untuk menyelesaikan, persyaratan/kelengkapan yang diperlukan (standar input) dan outputnya dengan uraian sebagai berikut:

Pengelolaan daftar hadir Kepegawaian berdasarakan Standart Operating Prosedure (SOP) di inspektorat provinsi kepulauan riau. Rekapitulasi daftar hadir pegawai dimulai dengan menyiapkan daftar hadir dan absensi finger print pada jam 07.30 s/d jam 16.00 setiap harinya. Seterusnya petugas absensi finger print mengentri data daftar hadir setiap datang dan pulang setiap harinya dan memantau absensi finger print setiap hari kerja. Mencatat pegawai yang tidak hadir sesuai dengan keterangan pegawai yang bersangkutan pada buku daftar hadir dan melakukan sinkronisasi dengan penugasan di bagian keuangan. Menghimpun surat keterangan tidak hadir pegawai dan daftar hadir yang ditandatangani oleh sekretaris dan kasubag kepegawaian. Dan menyampaikan kebagian analisis daftar hadir sebagai bahan evaluasi.

b) Adanya komitmen pimpinan terhadap peningkatan kompetensi Pegawai

Peningkatan Kompetensi Pegawai merupakan bagian dari terciptanya lingkungan pengendalian yang baik di inspektorat dalam mendukung pelaksanaan tugas dan fungsi dan untuk mencapai tujuan 
FisiPublik : Jurnal IImu Sosial dan Politik

https://journal.uwgm.ac.id/index.php/fisipublik

P-ISSN: 2528-2689; E-ISSN: 2540-9751

Vol 04 No 01 Mei 2019,

organisasi dan pelaksanaan sistem pengendalian intern pemerintah. Hal ini senada dengan penelitian Herawati (2014:7) bahwa didalam lingkungan pengendalian merupakan pengendalian yang mempengaruhi keseluruhan organisasi dan menjadi "atmosfir individu organisasi di dalam melakukan aktivitas dan melaksanakan tanggung jawab atas pengendalian yang menjadi bagiannya. Di kerenakan inspektorat merupakan suatu organisasi contoh bagi Organisasi perangkat daerah lainnya dalam pelaksanaan seluruh kegiatan supaya sesuai dengan aturan. Dikarenakan inspektorat juga sebagai organisasi perangkat daerah yang tugasnya nya melakukan pegawasan dan pembinaan maka sangat diperlukan untuk seluruh pegawai dalam meningkatkan kompetensi nya sebagai contoh semua fungsional auditor sekurang kurangnya sebelum turun melakukan tugas pemeriksaan di Organisasi perangkat daerah harus mempunyai sertifikat auditor dan sertifikat pengadaan barang dan jasa karena sangat berkaitan dengan pemeriksaan pengelolaan keuangan dan pengadaan baik itu belanja modal maupun jasa di seluruh organisasi perangkat daerah di lingkungan pemerintah provinsi kepulauan riau. Dari wawancara yang peneliti lakukan terhadap Informan mengenai Komitmen terhadap Kompetensi pegawai, maka dapat dianalisa dari Perencanaan perumusan kebijakan melalui ketersediaan anggaran yang sudah mengikuti diklat di tahun 2017 sebanyak dua puluh tiga orang orang sepuluh orang untuk auditor dan lima orang untuk pengawas penyelenggara urusan pemerintah daerah lima orang untuk pejenjangan sertifikasi dari auditor pertama ke auditor muda serta 3 orang yang sudah mengikuti diklat penunjang lainnya seperti diklat penyusunan laporan keuangan berbasis akrual. Dari lima puluh lima orang jumlah pegawai di inspektorat provinsi kepulauan riau dengan ketersediaan anggaran diklat untuk tiga puluh orang maka dapat di analisa komitmen inspektur provinsi kepulauan riau dalam peningkatan kompetensi pegawai sudah cukup baik dikarenakan dari jumlah total keseluruhan pegawai sebanyak lima puluh lima orang pegawai dan target yang mengikuti diklat pada tahun 2017 sebanyak tiga puluh orang sudah 
FisiPublik : Jurnal IImu Sosial dan Politik

https://journal.uwgm.ac.id/index.php/fisipublik

P-ISSN: 2528-2689; E-ISSN: 2540-9751

Vol 04 No 01 Mei 2019,

terpenuhi. Karena dari jumlah pegawai rata rata semuanya sudah mengikuti diklat dan sudah memiliki sertifikasi auditor.

\section{Penilaian Resiko}

Penilaian Resiko sebagai salah satu unsur dalam peraturan pemerintah nomor 60 tahun 2008 tentang SPIP di pasal 13 ayat (1) bahwa pimpinan instansi wajib melakukan penilaian resiko. Dengan diterbitkan peraturan gubernur kepulauan riau nomor 59 tahun 2016 tanggal 19 desember tahun 2016 tentang pedoman penilaian resiko di lingkungan pemerintah provinsi kepulauan riau maka dapat menjadi acuan oleh seluruh perangkat daerah dan khususnya inspektorat provinsi kepulauan riau dalam memberikan petunjuk dan melakukan pemetaan resiko sekaligus mendorong pegawai untuk mempertimbangkan resiko dalam pengambilan keputusan dan Penyusunan tujuan dan Sasaran kinerja Inspektorat.

Penilaian resiko dimulai dengan penetapan tujuan dan sasaran Inspektorat Provinsi Kepulauan riau yang sesuai dengan rencana strategis provinsi dan rencana kerja SKPD. penilaian resiko terdiri dari dua jenis kegiatan utama yaitu identifikasi resiko dan analisis resiko peristiwa yang mungkin dapat menghambat pencapaian tujuan dan sasaran kerja inspektorat provinsi kepulauan riau. Adapun sasaran kinerja inspektorat Output identifikasi resiko adalah daftar resiko yang memuat informasi dan peristiwa tentang resiko. Berdasarkan keputusan gubernur Kepulauan Riau Nomor 59 Tahun 2016 tentang penilaian resiko adapun ruang lingkup penilaian resiko pada setiap perangkat daerah pada tiga tingkat tindakan dan kegiatan, yaitu :

1. Tingkat strategis yang meliputi penilaian resiko pada aspek strategis yang menjadi tanggungjawab kepala daerah. Salah satunya dengan membuat peraturan dan pedoman penilaian resiko nomor 59 tahun 2016 tentang penilaian resiko.

2. Tingkat organisasional yang meliputi penilain resiko perangkat daerah yang bersifat manajerial manajemen dibawah kepala perangkat daerah. Yaitu 
FisiPublik : Jurnal IImu Sosial dan Politik

https://journal.uwgm.ac.id/index.php/fisipublik

P-ISSN: 2528-2689; E-ISSN: 2540-9751

Vol 04 No 01 Mei 2019,

kepala perangkat daerah dengan membuat daftar resiko dari tujuan dan sasaran kinerja inspektorat provinsi kepualaun riau.

3. Tingkat operasional yaitu penilaian resiko di tingkat kegiatan operasional disetiap perangkat daerah harus membuat analisis dan pemetaan resiko terhadap seluruh kegiatan.

\section{a. Identifikasi Resiko}

Dari wawancara yang dilakukan kepada sekretaris dan masing masing inspektur pembantu di inspektorat provinsi kepulauan riau diketahui bahwa jumlah kegiatan di inspektorat berdasarakan rencana kerja di tahun 2017 sebanyak 36 kegiatan yang telah dijabarkan dari enam program kegiatan. Dan di kuasakan ke sekretaris sebanyak tujuh belas kegiatan dan masing masing inspektur pembantu dikuasakan enam kegiatan.

Dari wawancara dengan Informan, maka dapat dianalisa bahwa secara teknis dari 17 kegiatan di Tahun 2017 yang dikuasakan belum sama sekali melakukan identifikasi resiko dengan membuat daftar resiko melaui kertas kerja penilaian resiko (KKPR) di setiap kegiatan. Ini menandakan SPIP belum dilaksanakan sepenuhnya di inspektorat provinsi kepulauan riau di tingkat operasional kegiatan di inspektorat provinsi kepulauan riau.

\section{Tabel 2}

Bukti Pendukung Penilaian Resiko

\begin{tabular}{|l|l|l|c|}
\hline \multicolumn{1}{|c|}{ UNSUR } & \multicolumn{1}{|c|}{ SUB UNSUR } & $\begin{array}{c}\text { BUKTI } \\
\text { PENDUKUNG / } \\
\text { RUJUKAN }\end{array}$ & CATATAN \\
\hline $\begin{array}{l}\text { Penilaian } \\
\text { Risiko }\end{array}$ & \begin{tabular}{l} 
1. $\begin{array}{l}\text { Penetapan Tujuan } \\
\text { pada Tingkat } \\
\text { Kegiatan Instansi }\end{array}$ \\
\cline { 2 - 5 }
\end{tabular} & $\begin{array}{l}\text { Renja, RKA dan } \\
\text { DPA }\end{array}$ & ADA \\
\cline { 2 - 5 } & 2. Identifikasi Risiko & & TIDAK ADA \\
\cline { 2 - 5 } & 3. Analisis Risiko & & TIDAK ADA \\
\hline
\end{tabular}

Sumber Informan A2 (Inspektorat Provinsi Kepulauan Riau)

\section{Kegiatan Pengendalian}

Yang dimaksud dengan kegiatan pengendalian adalah tindakan yang diperlukan untuk mengatasi risiko dalam usaha mencapai tujuan dan sasaran yang telah ditetapkan dalam bentuk kegiatan yang tujuannya untuk memastikan 
FisiPublik : Jurnal IImu Sosial dan Politik

https://journal.uwgm.ac.id/index.php/fisipublik

P-ISSN: 2528-2689; E-ISSN: 2540-9751

Vol 04 No 01 Mei 2019,

bahwa tindakan mengatasi risiko telah dilaksanakan secara efektif. Kegiatan pengendalian dilaksanakan dalam bentuk:

\section{a. laporan transaksi keuangan dengan cara mencatat dengan lengkap dan} akurat seluruh transaksi keuangan di setiap kegiatan.

Dari hasil wawancaran yang dilakukan dapat dianalisa bahwa dalam pembuatan laporan transaksi keuangan sudah menggunakan aplikasi SIMDA serta ada petugas yang mencatat dan memvertifikasikan segala bentuk transaksi keuangan baik dalam bentuk sistem dan pertanggungjawaban dokumentasi fisik. Pelaksana pembukuan adalah Bendahara Pengeluaran dengan membuat dan mengerjakan pembukuan sesuai tugas pokok dan fungsi secara tertib, cermat, teliti dan lengkap pada masing-masing format yang telah dibakukan. Langkah-langkah pembukuan:

a. Menyiapkan Buku Kas Harian, untuk mencatat transaksi kas (SP2D dan pengeluaran harian)

b. Membuat Buku Pembantu Kas

c. Membuat Buku Panjar/Persekot Kerja (mencatat pemberian panjar kerja kepada PPTK dan pengembalian panjar kerja)

d. Membuat buku bantu pajak. Membuat rekapitulasi belanja per rincian obyek belanja.

e. Membuat buku pembantu simpanan di bank

Hal tersebut merupakan kegiatan pengendalian yang utama karena menurut Tarigan, D. N., \& Warongan, J. D (2016:1548) Kegiatan pengendalian adalah tindakan yang diperlukan untuk mengatasi resiko serta penetapan dan pelaksanaan kebijakan dan prosedur untuk memastikan bahwa tindakan mengatasi resiko telah dilaksanakan secara efektif. Untuk itu langkah-langkah secara rinci dan sistematis dari SOP Buku Kas Umum terkait dengan kinerja setiap kegiatan yaitu mengidentifikasikan mutu baku tertentu, meliputi waktu yang diperlukan, persyaratan/kelengkapan yang diperlukan (standar input) dan outputnya dengan uraian sebagai berikut: 
FisiPublik : Jurnal IImu Sosial dan Politik

https://journal.uwgm.ac.id/index.php/fisipublik

P-ISSN: 2528-2689; E-ISSN: 2540-9751

Vol 04 No 01 Mei 2019,

\section{Informasi dan Komunikasi}

Informasi dan komunikasi dalam sistem pegendalian intern pemerintah dimaksud dengan keterbukaan anggaran yang dibagi disetiap perangkat daerah dalam hal pembagian anggaran yang tentunya sesuai dengan kewenangan yang diberikan gubernur dan berdasarkan tugas pokok dan fungsi inspektorat dalam pelaksanaan seluruh program kegiatan di inspektorat provinsi kepulauan riau. Serta dalam penyusunan dan besaran anggaran di intern inspektorat dalam penyusunan dan pembagian besaran pagu anggaran yang tentunya berdasarkan peraturan dan kewenangan yang diberikan kepala daerah. Informasi dan Komunikasi didalam SPIP di inspektorat provinsi kepulauan riau yang dilihat dari keterbukaan dalam pembagian dan penyusunan anggaran berdasarkan kewenangannya sudah dilakukan tetapi belum maksimal berdasarkan surat permendagri nomor : 700/435/A.2/IJ tanggal 07 april 2017 dan surat menteri dalam negeri nomor : 900/2900/SJ tanggal 23 september 2008 hal prioritas anggaran minimal $1 \%$ dari APBD untuk pembinaan dan pengawasan, telah diminta kepada kepala daerah untuk mengalokasi $1 \%$ APBD untuk anggaran pengawasan. Tetapi di tahun 2017 jumlah pembagian anggaran inspektorat belum mencapai $1 \%$ yakni 24,.533.422.750,- dari APBD 3,3 triliun.

\section{a. Keterbukaan informasi anggaran dalam penyusunan belanja kegiatan tambahkan penjelasan}

Dari wawancara yang dilkakukan terhadap informan mengenai informasi dan komunikasi dalam keterbukaan informasi anggaran dan keterbukaan terhadap masyarakat tentang besaran anggaran sebagai bentuk transparansi pemerintah kepada masyarakat sudah dilaksanakan secara terbuka melalui website pemerintah provinsi kepri dan melalui surat kabar dan media elektronik. Dan mengenai penyusunan kegiatan apakah sesuai dengan renja dan renstra sudah sesuai sebagai contoh dalam program peningkatan kompetensi tenaga pemeriksa sudah disusun tiga kegiatan konkrit yaitu peningkatan kompetensi APIP, Peningkatan Kompetensi tenaga penunjang pengawasan, dan pelatihan kantor sendiri atau lebih dikenal dengan nama in house training yang bertujuan untuk pengembangan 
FisiPublik : Jurnal IImu Sosial dan Politik

https://journal.uwgm.ac.id/index.php/fisipublik

P-ISSN: 2528-2689; E-ISSN: 2540-9751

Vol 04 No 01 Mei 2019,

dan peningkatan kualitas pengawasan di lingkungan pemerintah provinsi kepulauan riau.

\section{Pemantauan Pengendalian}

Untuk memastikan apakah SPIP dapat berjalan sesuai dengan pengendalian di seluruh unsur kegiatan, maka pemantauan dan monitoring dapat dilakukan dengan membandingkan dikumen rencana tindak pengendalian dengan anggaran yang tersedia dan memantau data aset apakah sudah sesuai dengan standart satuan harga atau tidak serta merekonsiliasi aset apakah sudah sesuai dengan fisik nya. Pemantauan tersebut dilakukan melalui:

a. Membandingkan dokumen rencana tindak pengendalian (RTP) apakah telah sesuai dengan jumlah seluruh kegiatan dan sesuai dengan anggaran yang disediakan.

Membandingkan Rencana Tindak Pengendalian bertujuan untuk mengetahui selama kegiatan diadakan apakah sesuai dengan anggaran yang disediakan cukup atau tidak, kemudian kemudian sebagai output dokumen dalam mengatasi resiko resiko yang terjadi dalam pelaksanaan kegiatan.

Adapun jawaban yang di peroleh dari informan dengan penjelasan yang diberikan belum dibuatnya rencana tindak pengendalian disetiap kegiatan operasional dalam rangka untuk mengetahui sejauh mana ketersediaan anggaran dapat mendukung terlaksananya dengan maksimal disetiap kegiatan.

b. Memantau belanja dan laporan data aset kegiatan telah sesuai dengan standard satuan harga dan harga pasar.

Jawaban yang di peroleh dari informan dengan penjelasan yang diberikan bahwa untuk belanja seluruh kegiatan per kode rekening sudah sesuai dengan standart satuan harga pemerintah provinsi kepulauan riau. Karena standart satuan harga sudah mengacu kepada seluruh harga pasar diseluruh provinsi kepulauan riau.

c. Melakukan rekonsiliasi aset di setiap bidang. Jika terjadi kesalahan transaksi keuangan kerusakan aset, dan aset yang tidak sesuai dengan fisiknya 
FisiPublik : Jurnal IImu Sosial dan Politik

https://journal.uwgm.ac.id/index.php/fisipublik

P-ISSN: 2528-2689; E-ISSN: 2540-9751

Vol 04 No 01 Mei 2019,

Pelaksanaan rekonsiliasi yang dilakukan apabila terjadi kesalahan transaksi keuangan bahwa untuk rekonsiliasi asset sudah dilakukan dengan bagian aset BPKKD sebagai penanggungjawab barang dan aset daerah dan di inspektorat sendiri sudah dilaksanakan oleh pemegang dan pengurus barang dengan merekonsialisasi aset aset dan barang di inspektorat dengan menerbitkan kartu inventaris barang disetiap ruangan dan membuat laporan pemegang dan pengurus barang kepada sekretaris pertriwulan di inspektorat provinsi kepulauan riau.

Dari wawancara yang dilakukan dapat dianalisa bahwa dalam membuat dokumen rancana tindak pengendalian (RTP) bentuk dokumennya belum dibuat diseluruh kegiatan di inspektorat. Ini menandakan monitoring untuk melakukan perbandingan antara jumlah kegiatan dengan anggaran yang disediakan tidak dapat dilakukan. Karena kita tidak dapat mengetahui resiko resiko apa saja yang ada disetiap kegiatan. Untuk belanja dan laporan data aset kegiatan apakah telah sesuai dengan standard satuan harga dan harga pasar yang disesuaikan dengan standart satuan harga provinsi kepulauan riau tahun 2017 yang menjadi acuan seluruh perangkat daerah dalam menentukan kode rekening belanja kegiatan.

Kelima unsur tersebut memiliki kaitan yang erat satu sama lainnya dan seluruh proses berjalan terus menerus antara pegawai dan pimpinannya. SPIP ini memungkinkan bagi masing - masing pegawai untuk melakukan pengendalian atas diri mereka sendiri terlepas apakah pimpinan akan menilai/mengawasi ataupun tidak. Pelaksanaan SPIP dibutuhkan pembinaan Sumber Daya Manusia yang tepat sehingga tujuan organisasi dapat tercapai. Keberadaan Aparat Pengawasan Intern Pemerintah (APIP) yang dalam hal ini berada di tangan Inspektorat dan seluruh jajaran auditor-nya juga perlu ditetapkan dan diberdayakan secara tepat agar dapat bertindak dengan lebih efektif. Kedepan diharapkan APIP dapat sebagai quality control agar kegiatan dilakukan secara efektif dan efisien, tidak terjadi pelanggaran agar tujuan organisasi dapat tercapai. Terdapat kode etik yang harus dijalankan oleh auditor dalam upaya pelaksanaan 
FisiPublik : Jurnal IImu Sosial dan Politik

https://journal.uwgm.ac.id/index.php/fisipublik

P-ISSN: 2528-2689; E-ISSN: 2540-9751

Vol 04 No 01 Mei 2019,

tugas sebagai APIP yang diatur dalam Peraturan Menteri Pemeberdayaan Aparatur Negara nomor PER04/M.PAN/03/2008 tentang kode etik APIP.

Dalam melakukan fungsi dan tugasnya sebagai aparat pengawasan, Satuan Tugas APIP memerlukan adanya koordinasi yang cukup baik dengan Satuan unit kerja yang lain dalam pola pembinaan dan juga lebih baik dalam merespon pengaduan masyarakat. Dalam pemerintahan di daerah, diperkuat dengan terbitnya Peraturan. Sebagai instansi yang memiliki tugas pokok, fungsi dan kewenangan sebagai instansi pengawasan internal Pemerintah Provinsi Kepulauan Riau ,Inspektorat Provinsi Kepulauan Riau memiliki tugas utama dalam memberikan pembinaan dan pengawasan kepada seluruh instansi dalam lingkup Pemerintah Provinsi Kepulauan Riau termasuk para Pegawai didalamnya. Ini menjadi faktor penentu untuk peningkatan profesionalisme APIP dan inspektorat sebagai instansi yang memberikan contoh kepada seluruh organisasi perangkat daerah untuk dapat menjalankan seluruh program kegiatan yang sesuai dengan aturan dan kebijakan yang berlaku yang tentunya dapat memperhitungkan resiko resiko yang terjadi baik dari perencanaan tujuan dan sasaran, penyusunan rencana kerja dan penyusunan anggaran tersedia yang tentunya sesuai dengan kewenangan yang diberikan sehingga tidak terjadi penyalahgunaan dan penyimpangan terhadap pelaksanaan program kegiatan dan anggaran di seluruh organisasi perangkat daerah di lingkungan pemrintah provinsi kepulauan riau.

\section{Kesimpulan}

Dari hasil wawancara yang dilakukan pada semua informan tentang lima unsur SPIP didalam organnisasi di inspektorat provinsi kepulauan riau dapat di analisa bahwa SPIP pada Inspektorat Provinsi Kepulauan Riau Telah diterapkan tapi belum baik karena kelima sub unsur SPIP mempunyai keterkaitan yang kuat satu sama lain. Dalam lingkungan pengendalian yang dapat dilihat dari sistem pengendalian intern pemerintah di inspektorat yaitu penegakan nilai etika dan integritas dari pimpinan belum cukup baik harus terus ditingkatkan lagi dalam pemberian contoh tauladan dalam kataatan dan ketepatan waktu jam kerja, dilakukan rapat rapat kecil sebagai bentuk pola komunikasi yang baik antara 
FisiPublik : Jurnal IImu Sosial dan Politik

https://journal.uwgm.ac.id/index.php/fisipublik

P-ISSN: 2528-2689; E-ISSN: 2540-9751

Vol 04 No 01 Mei 2019,

pimpinan dan pegawai sehingga berdampak positif kepada lingkungan organisasi secara menyeluruh menenai komitmen pimpinan terhadap kompetensi pegawai di inspektorat provinsi kepulauan riau sudah sangat baik dikarenakan dari target 30 orang yang akan ikut pendidikan dan pelatihan di tahun 2017 sebanyak 30 orang sudah sebanyak 25 orang pegawai yang ikut dan dan uji kompetensi diklat aparat pengawas intern pemerintah (APIP) maupun dari pengawas penyelenggara urusan pemerintah daerah (P2UPD) serta diklat penunjang lainnya.

Penilaian Resiko di inspektorat sebagai salah satu bentuk terselenggaranya SPIP yang terbagi menjadi tiga tingkatan yaitu di tingkat strategis yaitu kebijakan kepala daerah dengan mengeluarkan keputusan gubernur nomor 59 tahun 2016 tentang pedoman penilaian resiko sudah cukup baik dengan landasan pedoman ini setiap perangkat daerah bisa menilai resiko resiko apasaja yang bisa terjadi dalam pencapaian tujuan dan sasaran organisasi. Tingkat yang kedua yaitu di tingkat organisasional dengan melihat tujuan dan sasaran perangkat daerah dalam mendukung program kepala daerah guna mendukung terwujudnya visi dan misi gubernur di bidang akuntabilitas sudah dilaksanakan sampai di level terdefinisikan dalam penilaian SPIP ini menandakan bahwa kegiatan SPIP sudah dijalankan dan terdokumentasikan dengan baik tapi belum dilakukan evaluasi yang memadai. Tingkat yang ketiga yaitu tingkat operasional yaitu mengidentifikasi resiko diseluruh kegiatan di inspektorat provinsi kepulauan riau. Ini belum dilakukan sama sekali oleh para kuasa pengguna anggaran dan pejabat pelaksana teknis kegiatan yang mempunyai tanggungjawab langsung baik manajerial dan teknis pada seluruh kegiatan di inspektorat provinsi kepulauan riau.

Kegiatan pengendalian merupakan kegiatan yang dilakukan untuk mengatasi resiko resiko di setiap kegiatan tetapi dikarenakan resiko kinerja diseluruh kegiatan operasional di inspektorat belum dilaksanakan maka dilihat dari pencatatan transaksi keuangan diseluruh kegiatan di inspektorat provinsi kepualauan riau dalam hal pengendalian aliran kas diseluruh kegiatan dengan menerbitkan kartu kendali kegiatan dan buku kas umum dalam pencairan kas 
FisiPublik : Jurnal IImu Sosial dan Politik

https://journal.uwgm.ac.id/index.php/fisipublik

P-ISSN: 2528-2689; E-ISSN: 2540-9751

Vol 04 No 01 Mei 2019,

kegiatan yang dilaksankan sudah cukup baik secara sistem informasi management daerah dan secara pertanggungjawaban fisik.

Informasi dan Komunikasi didalam SPIP di inspektorat provinsi kepulauan riau yang dilihat dari keterbukaan dalam pembagian dan penyusunan anggaran berdasarkan kewenangannya sudah dilakukan tetapi belum maksimal berdasarkan surat mendagri nomor : 700/435/A.2/IJ tanggal 07 april 2017 dan surat menteri dalam negeri nomor : 900/2900/SJ tanggal 23 september 2008 hal prioritas anggaran minimal $1 \%$ dari APBD untuk pembinaan dan pengawasan, telah diminta kepada kepala daerah untuk mengalokasi $1 \%$ APBD untuk anggaran pengawasan. Tetapi di tahun 2017 jumlah pembagian anggaran pengawasan belum mencapai $1 \%$ yakni 24,.533.422.750,- dari APBD 3,3 triliun. Terkait dengan keterbukaan informasi anggaran.

Pemantauan dan monitoring SPIP di inspektorat provinsi kepulauan riau yang mengharuskan adanya dokumen tindak pengendalian sampai ditingkat operasionalisasi kegiatan belum dilakukan dengan membuat kertas kerja pengendalian kegiatan dan pemetaan resiko setiap kegiatan. Baik dalam membandingkan kebutuhan belanja kegiatan dengan jumlah anggaran yang tersedia maupun membandingkan dengan standar satuan harga provinsi kepulauan riau. Serta dokumen rencana tindak pengendalian atas laporan rekonsiliasi aset dengan membandingkan laporan dengan fisiknya.

\section{Daftar Pustaka}

Moleong, lexy J (2007).Metode Penelitian Kualitatif. Bandung : PT. Remaja Rosdakarya.

Moleong, Lexy J. (2001), Metode Penelitian Kualitatif, cetakan keempatbelas, Bandung: PT Remaja Rosdakarya (anggota IKAPI).

Sugiono. (2005). Metode Penelitian Administrasi. Bandung: PT. Alfabeta

Sugiyono. (2006). Metode Penelitian Kuantitatif Kualitatif dan R\&D. Bandung: Alfabeta

Peraturan Daerah Provinsi Kepulauan Riau Nomor 5 Tahun 2011 Tentang Organisasi dan Tata Kerja SKPD Provinsi Kepulauan Riau. 
FisiPublik : Jurnal IImu Sosial dan Politik

https://journal.uwgm.ac.id/index.php/fisipublik

P-ISSN: 2528-2689; E-ISSN: 2540-9751

Vol 04 No 01 Mei 2019,

Peraturan Gubernur Nomor 21 Tahun 2012 Tentang Tugas, Fungsi dan Uraian Tugas Inspektorat Kepulauan Riau.

Peraturan Gubernur Nomor 16 Tahun 2012 Tentang SPIP.

Keputusan Gubernur Nomor 370 Tahun 2011 Petunjuk Penyelenggaraan SPIP.

Undang-Undang Nomor 01 Tahun 2004 Pembendaharaan.

Peraturan Pemerintah 60 Tahun 2008.

Standard Operating Procedure (SOP) Inspektorat Provinsi Kepulauan Riau Tahun 2013

Keputusan Gubernur Kepulauan Riau Nomor 59 Tahun 2016 Tentang Pedoman Penilaian Resiko Di Lingkungan Pemerintah Provinsi Kepulauan Riau.

Standard Satua Harga (SSH) Provinsi Kepulauan Riau Tahun 2017

Surat Edaran Menteri Dalam Negeri Nomor 700/435/A.2/IJ Tanggal 07 April Tahun 2017 Tentang

Peraturan Gubernur Nomor 37 Tahun 2016 Tentang Penyelenggaraan Sistem Pengendalian Intern Pemerintah Di Lingkungan Pemerintah Provinsi Kepulauan Riau Tahun Anggaran 2016

Intruksi Presiden Nomor 1 Tahun 1989 tentang Pengawasan Melekat (WASKAT)

Peraturan Badan Pengawasan Keuangan dan Pembangunan (BPKP) nomor 4 Tahun 2016 Tentang Pedoman Penilaian dan Strategi Peningkatan Maturitas SPIP. 